Historia Contemporánea 52: 9-42

ISSN: $1130-2402-$ e-ISSN: $2340-0277$

DOI: $10.1387 /$ hc. 15728

\title{
MUJERES VIRILES EN EL SIGLO XVIII: LA CONSTRUCCIÓN DE LA FEMINIDAD POR EL DISCURSO FORALISTA DE MANUEL DE LARRAMENDI ${ }^{1}$
}
VIRILE WOMEN IN THE 18TH CENTURY: THE CONSTRUCTION OF FEMININITY BY THE REGIONALIST DISCOURSE OF MANUEL DE LARRAMENDI

\author{
Bakarne Altonaga Begoña \\ Universidad del País Vasco/Euskal Herriko Unibertsitatea
}

Entregado el 23-12-2014, aceptado 4-12-2015.

\begin{abstract}
Resumen: Este artículo analiza la construcción de la diferencia sexual en la discurso foralista de Manuel de Larramendi. Nos centramos en la relación entre las variables identitarias de comunidad, género, clase y religión en su crónica sobre Gipuzkoa a través del análisis de tres temas centrales en sus discursos: el del trabajo, el del atuendo y el de los bailes tradicionales. En ellos observaremos cómo el autor construyó un ideal de perfección viril, física y moral, que los habitantes de la provincia, valedores de la excepcionalidad de sus tradiciones y costumbres, debían incorporar. Pese a la misoginia que subyacía en el pensa-
\end{abstract}

${ }^{1}$ La realización de este trabajo se inscribe en el contrato predoctoral para la Formación del Personal Investigador concedido por la UPV/EHU (2013). Forma parte, así mismo, del Grupo de Investigación Universitario de la UPV/EHU titulado: «La experiencia de la sociedad moderna en España, 1870-1990», GIU 11/22, la UFI 11/27 y el proyecto del MINECO código: HAR2012-37959-C02-01. Por último, quisiera mostrar mi agradecimiento a la profesora Nerea Aresti Esteban por la atenta lectura del presente texto, sus sabios consejos y aportaciones. 
miento hondamente religioso y jerárquico del autor, característico del Antiguo Régimen, en su discurso también las mujeres fueron partícipes de los valores varoniles de la esencia guipuzcoana. Sus ideales de feminidad convivieron y debatieron con las propuestas ilustradas que comenzaban, ya hacia mediados del siglo XVIII, a tomar cuerpo tanto en España como en Europa.

Palabras clave: Feminidad, foralismo, mujeres, Antiguo Régimen, Ilustración.

\begin{abstract}
This article analyzes the construction of sexual difference by the regionalist discourse of Manuel de Larramendi. I will focus on the relation between the categories of community, gender, class and religion in his chronicle about Gipuzkoa through the study of three issues: his view on work, costumes and traditional dances. The author created an ideal of virile perfection, physical and moral, that every member of the community, as representatives of their exceptional traditions and customs, had to incorporate. Despite the fact that his ecclesiastical and hierarchical beliefs, distinctive of the Ancient Regime, were strongly misogynistic, the women of Gipuzkoa were also considered to embody the virile values that characterized the essence of the province. His ideals of femininity coexisted and discussed with the proposals of the Enlightenment that were beginning to substantiate and strengthen by the middle of the century, both in Spain and in Europe.
\end{abstract}

Key words: Femininity, regionalism, women, Ancient Regime, Enlightenment. 
En 1726, en una defensa ilustrada racionalista de la igualdad de capacidades intelectuales de mujeres y hombres, Benito Jerónimo Feijoo afirmaba en su Teatro Crítico Universal que: «Mi voto, pues, es que no hay desigualdades en las capacidades de uno y otro sexo.»². Dos décadas más tarde, en 1754, Manuel de Larramendi escribía en su Corografía de Guipúzcoa sobre las mujeres de la provincia que eran «de valor superior a su sexo, no tan espantadizas como en otras provincias» y que durante los numerosos episodios bélicos que enfrentaron a España con Francia en tierras guipuzcoanas «algunas y muchas han hecho cosas hazañosas y muy varoniles» ${ }^{3}$. Manuel de Larramendi y Jerónimo Feijoo construyeron dos discursos sobre la feminidad que, no siendo diametralmente opuestos, diferían en aspectos fundamentales. Estas divergencias emanaban y se enmarcaban en un contexto de debate en torno a la relación entre los sexos y responden a la defensa de líneas de pensamiento en disputa sobre la diferencia sexual, insertas a su vez en un momento histórico de importantes cambios en España y en Europa: el llamado Siglo de las Luces, que adoptó tintes distintos dependiendo del contexto.

El siglo XVIII ha demostrado ser un periodo especialmente fructífero para la historiografía de género. El interés por los discursos y conceptos que la reforma ilustrada introdujo ha redundado en una vasta producción académica. Los nuevos análisis dedicados a la construcción de los modelos de feminidad y masculinidad elaborados desde el proyecto ilustrado han conseguido ocupar un lugar destacado durante las dos últimas décadas en este ámbito intelectual ${ }^{4}$. En el presente artículo, sin embargo, pro-

${ }^{2}$ Benito Jerónimo Feijoo, Defensa de la mujer, Edición de Victoria Sau, Icaria, Barcelona, 1997, [1726] p. 73.

3 Manuel de Larramendi, Corografía de Guipúzcoa, Sociedad Guipuzcoana de Ediciones y Publicaciones, San Sebastián, 1969 [1754], p. 190.

${ }_{4}$ En el ámbito historiográfico español, la labor investigadora realizada por Isabel Morant y Mónica Bolufer es referencia obligada. Ver, entre otras obras, Isabel Morant, «Mujeres ilustradas en el debate de la educación. Francia y España», Cuadernos de Historia Moderna. Anejos, 3, 2004, pp. 59-84; «Las representaciones del matrimonio en la literatura ilustrada», en Eliseo Serrano Martín (ed.), Felipe V y su tiempo: congreso internacional, Institución Fernando el Católico, Zaragoza, 2004, pp. 507-528; Mónica Bolufer, Mujeres e Ilustración. La construcción de la feminidad en la España del siglo XVIII, Institució Alfons el Magnànim, Valencia, 1998; «Mujeres e Ilustración: una perspectiva europea», Cuadernos de Historia Moderna. Anejos, 6, 2007, pp. 181-201, o su texto más reciente «Multitudes del yo: biografía e historia de las mujeres», Ayer, 93, 2014, pp. 85-116. También en el ámbito de la historia Oliva Blanco, La polémica feminista en la España ilustrada, Almud, Ciudad Real, 2010. En el ámbito de la filosofía ver Celia Amorós, Teoría feminista: de la 
pongo dirigir la mirada hacia un discurso sobre la feminidad que se distancia de los planteamientos de voluntad modernizadora de la Ilustración. El objetivo es acercarnos a otros discursos, concretamente a los de naturaleza tradicionalista, que defendieron la necesidad de mantener los ideales de feminidad de acuerdo a los principios sociales y morales del Antiguo Régimen. Para ello he elegido la figura del clérigo jesuita y filólogo guipuzcoano Manuel de Larramendi (1690-1766) .

El alegato de Larramendi por la recuperación de las visiones tradicionales de género se enmarcó en un proyecto de carácter más general: la apología de la singularidad provincial de Gipuzkoa. Esta se tradujo en la defensa a ultranza de sus fueros, lengua y costumbres, en un contexto de cambio en las dinámicas sociales y políticas que también afectó a las relaciones administrativas entre los entes provinciales vascos y la Corona, representada esta por la recién instalada dinastía borbónica ${ }^{6}$.

Nos centraremos, pues, en el análisis de la construcción discursiva de la diferencia sexual por el discurso foralista ${ }^{7}$ de Manuel de Larramendi. Frente a la voluntad centralizadora que la nueva monarquía borbónica había mostrado, el jesuita se propuso reforzar la identidad provincial guipuzcoana, otorgándole un carácter diferenciado y singular a través del relato de su particular historia, legislación y costumbres ${ }^{8}$. La provincia y sus habitantes debían ser valedores de la tradición y la religión, del noble es-

Ilustración a la globalización, Minerva Ediciones, Madrid, 2005, Tiempo de feminismo: sobre feminismo, proyecto ilustrado y postmodernidad, Cátedra, Madrid, 1997. Y en el de la sociología, Rosa Cobo, «Un filósofo feminista no século XVIII: Poullain de la Barre», Festa de Palabra Silenciada, 22, 2006, pp. 6-10.

5 Para una aproximación a la vida y obra del autor véanse: Luis Michelena, La obra del P. Manuel de Larramendi (1690-1766), Universidad de Oviedo, Oviedo, 1959; J. Ignacio Tellechea, «Introducción», en Corografía de Guipúzcoa, Sociedad Guipuzcoana de Ediciones y Publicaciones, San Sebastián, 1969, pp. I-XXXV; Andrés Alberdi, Manuel de Larramendi (1690-1766), Gobierno Vasco, Vitoria, 1990; Joseba Andoni Lakarra (ed.), Manuel de Larramendi. Hirugarren mendeurrena 1690-1990, Ayuntamiento de Andoain, Andoain, 1992.

6 Véase Pablo Fernández Albaladejo, «Manuel de Larramendi: la particular historia de Guipúzcoa», Saioak, 1, 1977, pp. 148-156.

7 Sigo aquí la distinción entre foralismo y fuerismo ofrecida por Javier Fernández Sebastián, La génesis del fuerismo: prensa e ideas políticas en la crisis del Antiguo Régimen (País Vasco, 1750-1840), Siglo XXI, Madrid, 1991, p. 2.

8 Véase también Manuel de Larramendi, Sobre los fueros de Guipúzcoa: conferencias curiosas, políticas, legales y morales sobre los fueros de la m.n. y m.l. provincia de Guipúzcoa, Sociedad Guipuzcoana de Ediciones y Publicaciones, San Sebastián, 1983. 
píritu primitivo que desde tiempos inmemoriales había otorgado un carácter singular y una esencia imperturbable al lugar. La construcción de la diferencia sexual jugó un papel imprescindible en esta empresa. En aras de mostrar a sus convecinos como portadores de dicha excepcionalidad, fabricó un modelo de perfección viril, que representaba la encarnación de su superioridad moral, al que tanto hombres como mujeres debían responder. Varoniles labradoras, aguerridas amazonas o austeras y piadosas caseras son los referentes femeninos que propuso para la provincia. Estas imágenes de mujeres fuertes en el ámbito físico y espiritual, vendrían a contrastar con los modelos de feminidad de las propuestas ilustradas que, sobre todo a partir de la segunda mitad de siglo, presentarían a las mujeres como las representantes de los valores de la delicadeza, la sensibilidad y el recato en sentido laico, y cumpliendo los roles de esposa y madre de familia ${ }^{9}$. En este sentido, cabe destacar la aportación de la bilbaína Rita de Barrenechea que presentó en sus obras una comprensión de la feminidad, la familia y la sociedad vasca desde un prisma inequívocamente ilustrado $^{10}$.

Estudiaremos la construcción del canon larramendiano a través del análisis de tres discursos que resultaban imprescindibles en su visión del orden social: el trabajo, el atuendo y las danzas tradicionales. Estos tres aspectos de su discurso muestran de forma clara el modo en el que su visión de la feminidad y la relación entre los sexos estuvo estrechamente ligada a la construcción de la diferencia comunitaria. Permiten observar cómo su discurso sobre la identidad provincial se articuló sobre una relación de la dimensión de género con otras variables identitarias en la que la pertenencia a la comunidad, es decir, su férreo guipuzcoanismo, se imponía, y esto es significativo, tanto al género como a la jerarquía social o a las creencias religiosas. Sus concepciones de la provincia y de la diferencia sexual fueron elaboradas desde presupuestos característicos del Antiguo Régimen, pero no estuvieron exentas de singulares resignificaciones

9 Para un completo análisis de la concepción del género y la contribución de las mujeres durante la Ilustración véase Sarah Knott y Barbara Taylor (eds.), Women, Gender and Enlightenment, Palgrave Macmillan, Houndmills, 2005.

${ }^{10}$ Inmaculada Urzainqui (ed.), "Catalin» de Rita de Barrenechea y otras voces de mujeres en el siglo XVIII, Ararteko, Vitoria, 2006. Un desarrollo de esta cuestión podrá analizarse en Bakarne Altonaga, «The Basque Enlightenment: New Visions of Gender in the Crisis of the Antiguo Régimen», en S. Bermúdez y R. Johnson (eds.), A new History of Iberian Feminisms, University of Toronto Press, Toronto, en prensa. 
de ciertos elementos. No en vano, su crónica sobre Gipuzkoa fue un proceso fundamentalmente creativo, en el que aspectos vivos de la tradición se trenzaron con elementos mitificadores de los mismos, con el fin de generar la idea de un pasado inalterable al que el presente y el futuro debían corresponder ${ }^{11}$.

¿Por qué es relevante un estudio de esta naturaleza? En primer lugar, porque nos permitirá mostrar la tensión discursiva existente en torno a la generación de los nuevos ideales de género en un siglo de transición e introducción de nuevas perspectivas, en un momento marcado por cambios sociales y relativos a las identidades. Ciertos autores han tendido a relatar el dieciocho como el siglo de las luces, como el periodo que abanderó la idea de la razón y el progreso, también en lo que concierne a las identidades de género ${ }^{12}$. No obstante, el ejercicio benjaminiano de interpretar cada momento histórico sin hacer distinciones entre los grandes y pequeños acontecimientos me parece aquí necesario ${ }^{13}$. Si bien es cierto que durante el setecientos fueron los discursos ilustrados los que introdujeron planteamientos novedosos sobre la relación entre los sexos, convivieron con ellos numerosas voces discordantes, como la de Larramendi, que representaba la causa de una tradición amenazada. A pesar de que estos últimos no han merecido tanta atención como aquellos, creo importante prestarles atención con el objetivo de arrojar luz sobre el modo en el que diferentes significados de la categoría «mujeres» se construyeron mutuamente, en un momento discursivo abierto en el que ninguno estaba destinado a devenir en la norma que se impondría. En este sentido, varias autoras han acertado en mesurar el arraigo que las posturas ilustradas tuvieron en España, relativizando su capacidad para instalarse y hacerse mayoritarias en la mentalidad y sentir de la sociedad española dieciochesca ${ }^{14}$. Si bien es cierto que los ilustrados españoles compartieron con sus compañeros europeos las

11 Para un análisis de la construcción de la tradición vasca y sus mitos fundacionales durante los siglos XVIII y XIX véase Jon Juaristi, El linaje de Aitor: la invención de la tradición vasca, Taurus, Madrid, 1987.

${ }^{12}$ Los más recientes ejemplos en esta línea son: Jonathan Israel, Democratic Enlightenment: philosophy, revolution and human rights, 1750-1790, Oxford University Press, Oxford, 2013 o del mismo autor A revolution of the mind: radical enlightenment and the intellectual origins of modern democracy, Princeton University Press, Princeton, 2010.

13 Walter Benjamin, «Sobre el concepto de historia», en A. Useros y C. Rendueles (eds.), Escritos Políticos. Walter Benjamin, Abada, Madrid, 2012, [1942], p. 169.

${ }^{14}$ Isabel Morant, «Las representaciones del matrimonio...», pp. 508 y sig.; Mónica Bolufer, «Mujeres e Ilustración...», p. 191; Oliva Blanco, La Polémica Feminista..., p. 35. 
principales preocupaciones que caracterizaron al pensamiento ilustrado, también en lo que al género se refiere, el carácter más moderado de los planteamientos españoles, junto con el peso de la tradición, hacen necesario fijarse en los intercambios, flujos y efectos que pudieran darse entre posicionamientos de distinta naturaleza.

\section{El significado de la diferencia sexual: la encrucijada entre la tradición y la Ilustración}

¿En qué contexto intelectual y social debemos situar las concepciones de la feminidad y de la diferencia sexual de Manuel de Larramendi? El foralismo larramendiano ha sido generalmente considerado como radicalmente anti-ilustrado y anti-racionalista ${ }^{15}$. No obstante, conocemos por los catálogos de la biblioteca del Santuario de Loyola ${ }^{16}$, donde residió durante los últimos treinta años de su vida, y por su biblioteca personal ${ }^{17}$, que conocía la obra de los más importantes representantes de la Ilustración española, en particular Benito Jerónimo Feijoo y su Teatro Crítico, en el que encontramos el célebre discurso «Defensa de las mujeres». Es precisamente esta línea de pensamiento, la incipiente Ilustración española, con la que convivió nuestro autor.

La relación entre los sexos y las capacidades morales e intelectuales de las mujeres formarían el grueso de los temas de la «querelle des femmes», que comienza en el siglo XV y se extiende hasta el siglo XVIII, momento de reactivación de la polémica ${ }^{18}$. El debate de la «querella» aglutinó varios discursos en torno a la feminidad durante el Antiguo Régimen, desde aquellos profundamente misóginos que promulgaban la inferioridad de las mujeres y su asociación con el pecado, hasta aquellos que sostenían la superioridad y excelencia de algunas de ellas, en su dimensión «tanto

15 Javier Fernández Sebastián, La génesis del fuerismo..., p. 32.

16 Juan Iturriaga, Larramendi. Biblioteca del Santuario de Loyola. Catálogo e inventario de la Biblioteca personal del P. Manuel de Larramendi, Universidad de Deusto, Bilbao, 1992, p. 165.

17 Patxi Altuna, «La auténtica biblioteca de Larramendi», Muga, 28, 1978, pp. 74-81.

18 Véanse Cristina Segura, La querella de las mujeres, Asociación Cultural Al-Mudayna, Madrid, 2011; Mónica Bolufer, Mujeres e Ilustración..., p. 30 y de la misma autora «Las relaciones entre los sexos en el discurso ilustrado del progreso: España y Europa», en J. Astigarraga, M. V. López-Cordón y J. M. Urkia (eds.), Ilustración, ilustraciones, Real Sociedad Bascongada de Amigos del País, Astigarraga, 2009, pp. 793-809, p. 794. 
física como moral e intelectual, y la ilustraban con ejemplos históricos de mujeres célebres por su castidad, sabiduría, valor, capacidad política y guerrera» ${ }^{19}$.

Si bien es cierto que la intención de Larramendi nunca fue la de participar activamente en este debate, algunos de sus escritos dejan constancia de que en su imaginario existieron modelos de feminidad que respondían a los conceptos y creencias que operaron en los discursos de la «querella». Así queda de manifiesto en la arenga que escribió en su juventud, en 1716, en honor de la difunta Reina de España Margarita de Austria, que ensalzaba la figura de la reina. Las arengas o «margaritas» eran breves elogios fúnebres, recitados por alumnos destacados del colegio, dedicados, en este caso, a la difunta reina benefactora de la Compañía de Jesús. El texto es especialmente relevante en tanto que elogiaba las virtudes cristianas e intelectuales de la soberana, como queda recogido en su Autobiografía:

«Margarita tú misma acompañada de agilidad mental, sublime por la alteza de tu majestad, con la oculta virtud del espíritu. Hizo tu influencia que una vez se tuviera relación contigo. Pero se debe morir, Auditores. No es una prueba trivial de la verdad encontrar en Margarita la cultivación de las más selectas virtudes y parece haber ganado con ello la recompensa de la eterna vida» ${ }^{20}$.

A lo largo del texto se enaltecían los atributos intelectuales y políticos de la reina, su piedad y magnanimidad y, sobre todo, su devoción religiosa. Esta arenga se enmarca dentro de las coordenadas del ensalzamiento de una feminidad excepcional, que era alabada por incorporar en ella, y llevar al grado máximo de perfección, los valores propios de una elite aristocrática en una sociedad del privilegio. Se ensalzaba así el honor

19 Mónica Bolufer, Mujeres e Ilustración..., p. 30.

${ }^{20}$ La traducción es mía del original: «Margaritam, quae velocitate mentis te rotatum referens, celsitudine Maiestatis te sublime, occulta animi virtute tuos influxus quandam tecum cognationem contraxit? Sed moriendum est, Auditores; nec leve veritatis argumentum obiisse Margaritam, quae lectissimarum virtutum cultura, aeternum vivendi meritum comparasse videbatur». Fragmento reproducido de Manuel de Larramendi, Autobiografía y otros escritos, Sociedad Guipuzcoana de Ediciones y Publicaciones, San Sebastián, 1973, p. 66. Se trata de una compilación de textos biográficos de Larramendi elaborada por Ignacio Tellechea Idígoras. 
de una mujer, en singular, cuya superioridad frente a los límites que su género le imponía era signo de su condición estamental ${ }^{21}$.

También de su relación con la Reina María Ana de Neoburgo, viuda del último monarca de la Casa de Austria Carlos II y de quien Larramendi fue confesor en Bayona durante cuatro años (1730-1734), se desprende que en su visión de las mujeres el discurso sobre la excelencia femenina tuvo un peso decisivo. Como narró en varios pasajes recogidos en su $\mathrm{Au}$ tobiografía, su estancia en la corte francesa estuvo marcada por un desdichado altercado. Según relató, a consecuencia de ciertas calumnias vertidas en contra de la reina, Larramendi se vio en el deber de defender el honor de su penitente frente al rey Felipe V, viajando para ello a la corte de Sevilla. La reina había sido acusada de vivir de forma disipada, ciertamente escandalosa, por lo que desde la corte española se consideró menester trasladarla a un convento en España. El autor describió con detalle en su diario el viaje hasta Sevilla para defender de semejantes ultrajes el honor de «su Ama» y de «su honorífica Señora». A tales efectos escribió cinco Memoriales, entre los que destacan pasajes como el siguiente:

«La Reina, nuestra señora, no sólo no vive una vida escandalosa, sino que vive una vida virtuosa y santa, tan dedicada a los ejercicios de piedad y devoción, que apenas reserva nada de sí misma para las demás cosas. Una frecuencia muy grande de sacramentos; todo el día empleada a rezar multiplicadas devociones con sus criadas, en que es exactísima y puntual; ratos de meditación, lección de libros piadosos, exámenes repetidos de su conciencia, devotísima del Santo Sacrificio de la Misa. Corresponde al ejercicio interior de las virtudes cristianas la caridad y la misericordia admirada de cuantos conocen a Su Majestad, el agradecimiento, la paciencia y resignación en sus grandes trabajos y dolores, la abstracción, el retiro, la humildad y otras muchas. De manera que la Reina hoy día es un ejemplo de todas las Princesas» ${ }^{22}$.

El jesuita guipuzcoano quiso así destacar que la virtud de su reina era capaz de trascender los valores negativos (proximidad con el pecado y la lujuria, falta de capacidad intelectual, etc.) que otros discursos, como el puramente misógino, atribuían a las mujeres. Ella era capaz de cultivar las cualidades que estos últimos negaban al sexo femenino, como la práctica

21 Mónica Bolufer, «Galería de las «mujeres ilustres» o el sinuoso camino de la excepción de la norma cotidiana», Hispania, LX/I, 204, 2000, pp. 181-224, p. 192.

22 Manuel de Larramendi, Autobiografía..., p. 96. 
de la abstracción, la lectura de libros religiosos o el riguroso examen de conciencia.

A la luz de estas defensas cabe sugerir que Larramendi participaba de una visión de las mujeres característica de las sociedades que Thomas Laqueur denominó de sexo-único. El historiador estadounidense, en su ya clásico y también polémico estudio sobre la construcción del sexo en la historia, analizó el cambio de las sociedades del sexo-único, típico del Ancient Regime, dotadas de un único modelo sexual jerárquico, el masculino y una única línea de perfectibilidad humana, la viril, a sociedades del modelo de dos sexos, característico del pensamiento ilustrado, en las que la diferencia sexual comenzó a ser entendida en términos de complementariedad $^{23}$. La comprensión pre-ilustrada de la relación entre los sexos respondía a una «metafísica de la jerarquía» ${ }^{24}$ en la que las diferencias entre ambos sexos eran de grado y no especificas. Tal y como ha explicado Francisco Vázquez García, se trató de un complejo proceso de cambio del régimen del «sexo estamental», en el que «tener un sexo u otro era como pertenecer a un rango o estamento determinado», en el que cabía la posibilidad de tránsito entre los estamentos y los sexos, al régimen del «sexo verdadero», en el que las diferencias entre los géneros se certificaban a partir de una «codificación biológica» y que fijaba de forma inamovible el ser social de las personas ${ }^{25}$. La comprensión pre-ilustrada de la diferencia sexual se correspondía con una lógica social propia del Antiguo Régimen, en la que la misoginia y la jerarquización por estamentos era la norma y en la que las desigualdades estaban legitimadas como el orden natural de la sociedad ${ }^{26}$. La post-revolucionaria atendía a un concepto de pretendida igualdad que, mediante la reformulación de la tradicional misoginia en la idea de la complementariedad, obedecía a una jerarquización de las funciones sociales de cada sexo ${ }^{27}$. No obstante, estos cambios en la comprensión de la diferencia sexual no estuvieron sujetos a linealidad o necesidad

23 Thomas Laqueur, Making Sex. Body and gender from the Greeks to Freud, Harvard University Press, Cambridge, 1990. p. 8. Véase también Nerea Aresti, «Género e identidad en la sociedad del siglo XVII», Vasconia, 35, 2006, pp. 46-92.

${ }^{24}$ Thomas Laqueur, Making Sex..., p. 6.

25 Francisco Vázquez García, «Políticas transgenéricas y ciencias sociales: por un constructivismo bien temperado», en Teoría Queer: de la transgresión a la transformación social, Centro de Estudios Andaluces, 2009, pp. 4-14.

${ }^{26}$ Mónica Bolufer, Mujeres e Ilustración..., p. 31.

27 Mónica Bolufer, «Las relaciones entre los sexos en el discurso ilustrado del progreso...», p. 794 . 
histórica alguna. La trasformación de los significados atribuidos al sexo y al género tuvo lugar siempre en relación al contexto y coyuntura social donde se enmarcaban. Ciertamente, muchos elementos de las clásicas visiones del Antiguo Régimen perduraron en las sociedades contemporáneas, adquiriendo diferentes significados y conviviendo con nuevas percepciones de las diferencias entre los sexos.

En las coordenadas del régimen del «sexo estamental», el clásico argumento de la inherente imperfección femenina hizo del camino a la perfección un arduo empeño para las mujeres. No obstante, existieron en él espacios para la excepción y algunas de ella se les concedió la capacidad de trascender su condición de inferioridad y alcanzar la virtud mediante acciones o hazañas dignas de encomio ${ }^{28}$. Una de las particularidades de este régimen era la debilidad relativa del género en comparación con otros discursos contemporáneos, como elemento determinante de las identida$\operatorname{des}^{29}$. En ocasiones aspectos como la jerarquía, la pertenencia a una comunidad determinada, la piedad o las hazañas bélicas, tenían la capacidad de eclipsar al género permitiendo la excepcionalidad de algunas mujeres que trascendían su condición femenina, compartiendo así valores típicamente masculinos. Como señala la autora, no obstante, este tipo de concesiones no estuvieron reñidas con un pensamiento profundamente misógino, precisamente porque la adjudicación de la virtud, entendida como la superación de los defectos atribuidos al sexo femenino, emanaba de una concepción de la feminidad y de las mujeres extremadamente negativa ${ }^{30}$.

La cosmovisión larramendiana se caracterizó por incorporar la mencionada debilidad relativa del género con respecto a otros elementos de definición social. Como observábamos en su valoración de las magnánimas figuras de Margarita de Austria y María Ana de Neoburgo, el género quedaba eclipsado por el peso de la jerarquía social o la virtud religiosa. Y como analizaremos en lo que sigue, en su ensalzamiento de las varoniles y virtuosas caseras y aguerridas amazonas guipuzcoanas, el peso de la

${ }^{28}$ En nuestro contexto encontramos la famosa figura de Catalina de Erauso. Véanse Nerea Aresti, «Género e identidad...» y de la misma autora «The gendered identities of the «Lieutenant Nun»: Rethinking the story of a female warrior in Early Modern Spain», Gender \& History, vol. 19, 3, pp. 401-418.

${ }^{29}$ Nerea Aresti, «Género e identidad...», p. 60. Aresti desarrolla esta misma idea para otro contexto histórico en Nerea Aresti, «De Heroínas viriles a madres de la patria. Las mujeres y el nacionalismo vasco (1893-1937)», Historia y Política, 31, enero-junio, 2014, pp. 281-308, p. 284.

30 Nerea Aresti, «Género e identidad...», p. 60. 
identidad provincial prevalecía frente a otras características. En este sentido, el concepto de hidalguía universal, como característica provincial de Gipuzkoa, es de vital importancia, como se observará en lo que sigue. Trabajos como el de Oihane Oliveri Korta, que analizan las relaciones de género y el rol de las mujeres en la conformación del estamento hidalgo en Gipuzkoa durante la modernidad, son muy esclarecedores. Muestran el modo en el que algunas mujeres pudieron ejercer su autoridad en la configuración de los entramados familiares gracias a su condición de hidalgas, es decir, debido a su posicionamiento social y provincial $^{31}$.

El discurso de Larramendi sobre la feminidad fue una mezcolanza de argumentos ensalzadores de determinadas mujeres y valoraciones negativas de otras. Su uso de la retórica de la excelencia no pretendía ser parte de una apología generalizada de las capacidades de las mujeres al estilo feijooniano. Más bien al contrario, fue instrumentalizada como parte de una estrategia de singularización identitaria en el que se pretendían elogiar y privilegiar las virtudes de las mujeres guipuzcoanas frente a las debilidades de las mujeres, y también hombres, de otros lugares.

\section{La construcción de la excepcionalidad guipuzcoana: reinventando el gran mayorazgo divino}

La concepción larramendiana de la feminidad debe ser enmarcada, pues, en la defensa de unos códigos característicos de una cosmovisión fuertemente estamental, tradicionalista y religiosa, que pretendía fortalecer, además, una singularidad provincial mediante la defensa de la foralidad guipuzcoana ${ }^{32}$. El mayor control y centralización que la nueva

31 Véanse Oihane Oliveri Korta, Mujer, casa y estamento en la Gipuzkoa del siglo XVI, Diputación Foral de Gipuzkoa, San Sebastián, 2009 y de la misma autora Mujer y herencia en el estamento hidalgo guipuzcoano durante el Antiguo Régimen (siglos XVI-XVIII), Gipuzkoako Foru Aldundia, San Sebastián, 2001.

32 Sobre el pensamiento político de Manuel de Larramendi véase Pablo Fernández Albaladejo, «Imposible vencido, imposible vencida: la provincia invencible de Manuel de Larramendi», en Joseba Andoni Lakarra (ed.), Manuel de Larramendi. Hirugarren mendeurrena..., pp. 77-90; Javier Fernández Sebastián, La génesis del fuerismo..., pp. 34-40. Para una clara y concisa aclaración de los conceptos de cultura foral y poder provincial durante el Antiguo Régimen véanse J. M. Portillo y J. Viejo, «Estudio introductorio. La cultura del fuero entre historia y constitución», en Francisco de Aranguren y Sobrado, Aranguren y Sobrado, F. Demostración del sentido verdadero de las autoridades de que se vale el doctor D. Juan Antonio Llorente, UPV/EHU, Bilbao, 1994, pp. 25-43. 
monarquía de Felipe V quiso establecer sobre las competencias forales obtuvieron como respuesta la defensa a ultranza de sus fueros y su autonomía administrativa, generando un «discurso político de la foralidad provincial» ${ }^{33}$. Según Pablo Fernández Albaladejo, esta fue «una de las manifestaciones más contundentes sobre el reconocimiento de un hecho diferencial vasco con anterioridad al siglo XIX» ${ }^{34}$, pero que en ningún caso podría ser interpretada como un protonacionalismo ${ }^{35}$, sino más bien como el recrudecimiento de la defensa del poder provincial ante el despotismo borbónico, siempre desde las coordenadas sociales, relacionales y administrativas del Antiguo Régimen.

La cosmovisión de la Gipuzkoa de Larramendi quedó retratada en la ampliamente analizada Corografía de Guipúzcoa, escrita en 1754, pero que no fue editada hasta 1882. En esta obra, Larramendi concedía a la provincia la calidad de mayorazgo de origen divino, el primero de la península, caracterizado por la limpieza de sangre de sus pobladores al tratarse de un lugar que había resistido a cualquier conquista y que nunca se había mezclado con otras razas ${ }^{36}$. Los fueros representaban, en esta interpretación política, las leyes primigenias de la comunidad, su modo de ser esencial sin el cual la propia provincia quedaría abocada a la desaparición $^{37}$. Significaban la excelencia de una de las comunidades más antiguas de España, cuyos moradores hablaban un idioma, el euskera, también de origen divino, el más antiguo, puro y perfecto de la península. En esta construcción de carácter legendario, la defensa del mito del cristianismo primitivo servía para granjear a los guipuzcoanos y guipuzcoanas

33 Pablo Fernández Albaladejo, «Imposible vencido, imposible vencida»..., p. 85.

34 Pablo Fernández Albaladejo, «Manuel de Larramendi: la particular historia de Guipúzcoa»..., p.156.

35 Antonio Elorza, «El protonacionalismo de Larramendi», en Joseba Andoni Lakarra (ed.), Manuel de Larramendi. Hirugarren mendeurrena..., pp. 137-151.

${ }^{36}$ Sobre las raíces del concepto de nobleza provincial véanse José Ángel Achón Insausti, «La Provincia Noble. Sobre las raíces históricas de la «teoría foral clásica» y el discurso político de Esteban de Garibay», Eusko Ikaskuntza, 19, 2001, pp. 149-176 y del mismo autor «La «Casa Guipúzcoa». Sobre cómo una comunidad territorial llegó a concebirse en términos domésticos durante el Antiguo Régimen» en J. M. Imízcoz (dir.), Redes familiares y patronazgo. Aproximación al entramado social del País Vasco y Navarra en el Antiguo Régimen (siglos XV-XIX), UPV/EHU, Leioa, 2001, pp. 113-137.

37 Pablo Fernández Albaladejo, «El País Vasco: algunas consideraciones sobre su más reciente historiografía» en Roberto Fernández (ed.), España en el siglo XVIII. Homenaje a Pierre Vilar, Crítica, Barcelona, 1985, pp. 536-564. 
una calidad moral y virtud sobresalientes e incuestionables ${ }^{38}$. Esta mítica guipuzcoana culminaba con la extensión de la hidalguía a todos y cada uno de los habitantes de la provincia:

«Todo guipuzcoano que viene de alguno de los solares de Guipúzcoa siempre ha sido noble, siempre lo es y siempre lo será [...] Esta nobleza de sangre les viene por herencia, y suben con ella con la mayor limpieza del mundo hasta los primeros pobladores de España» ${ }^{39}$.

Detectamos fácilmente que este relato no solo no era descriptivo, sino que tampoco pretendía serlo. Surgía de la voluntad de reelaborar un pasado común y unos referentes que pudieran facilitar y justificar una identificación colectiva en el presente. Los temas de carácter más abstracto se combinaban con preocupaciones sobre cuestiones tocantes a la realidad inmediata de Gipuzkoa, que referían a la organización social del territorio: su actividad política, económica y comercial; la estructuración de los ámbitos laborales; el cumplimiento de las obligaciones religiosas e indumentarias, e incluso el respeto por las costumbres de carácter lúdico y festivo. La preocupación por construir referentes femeninos y masculinos que sirvieran como modelos físicos y morales de la esencia guipuzcoana impregna y da forma a estos discursos. Nos detendremos en analizar tres de estos elementos: el relativo al trabajo, el atuendo y los bailes.

\section{El noble cuerpo de las varoniles campesinas guipuzcoanas: sobre el ennoblecimiento del trabajo manual}

El proyecto social de Larramendi destaca por reivindicar una suerte de igualitarismo, basado en la universalización de la hidalguía, que no

38 Sobre la tradición mítica del vascoiberismo, vascocantabismo, tubalismo y monoteísmo primitivo que Larramendi recibe de autores como Garibay o Poza véanse Jon Juaristi, El linaje de Aitor..., pp. 48-58 y Carlos Martínez Gorriarán, Casa, Provincia y Rey: para una historia de la cultura del poder en el País Vasco, Alberdania, Irún, 1993, pp. 50-83. Sobre la construcción de la identidad vasca en relación a la doctrina católica véase Belen Altuna, El buen vasco. Génesis de la tradición «Euskaldun fededun», Hiria, San Sebastián, 2012.

39 Manuel de Larramendi, Corografía..., p. 135. Sobre el concepto de hidalguía universal véase Lourdes Soria Sesé, «La hidalguía universal», Iura Vasconiae, 3, 2006, pp. 283-316. 
obstante, lejos de entenderse a modo de democrático precursor del concepto de la igualdad moderna, requiere ser explicado a la luz de su contexto $^{40}$. Larramendi distinguió tres tipos de nobleza. La nobleza de sangre, de la que participaban todos los guipuzcoanos; la nobleza adquirida, aquella que se obtenía por medio de las hazañas bélicas o la acumulación de riquezas; y la nobleza de la virtud, que atañía a la calidad moral de cada guipuzcoano. Si bien mediante la nobleza de sangre se predicaba una especie de «igualación» de todos los guipuzcoanos en tanto que puros descendientes de los primeros moradores de la península, en la nobleza adquirida «que hace más o menos ilustres las casas y las familias [...] no son ni pueden ser iguales todos» ${ }^{41}$. La división estamental tradicional no quedaba, pues, en entredicho en la visión social larramendiana, pero la nobleza de sangre, aquella que ennoblecía a todos los guipuzcoanos desde tiempos inmemoriales, era de superior valor a la contingente y accidental nobleza adquirida. Tal y como planteó Javier Corcuera, en Larramendi «el sujeto de quien fundamentalmente se predica la nobleza es el campesino vasco, y el caserío, la fuente de hidalguía» ${ }^{42}$.

Esto así, Larramendi se vio en la obligación de resolver las contradicciones que emanaban de la defensa de la hidalguía universal de los guipuzcoanos, incluso de la de los más humildes labradores, pescadores y herreros, en un orden social cuyos pilares jerarquizadores eran las desigualdades derivadas de la posesión de la riqueza. La resolución de estas tensiones vino, en parte, de la mano de una revalorización del trabajo manual y la dignificación de la pobreza, ya que para él «los oficios de suyo no son viles, ni manchan ni deshonran [...] En Guipúzcoa nunca se han manchado los oficios, porque nunca han caído sobre sangre villana» ${ }^{43}$.

Su visión dignificadora contradecía las tradicionales concepciones del trabajo del Antiguo Régimen, que entendían el trabajo manual preñado de

40 Como muestran multitud de investigaciones al respecto, que los fueros de Bizkaia y Gipuzkoa recogiesen que los habitantes de las mismas pertenecían al estamento hidalgo en ningún caso supuso la igualdad política y efectiva de todos sus miembros. Entre otros véanse Pablo Fernández. Albaladejo, La crisis del Antiguo Régimen en Guipúzcoa, 17661833: cambio económico e historia, Akal, Madrid, 1975, pp. 366 y sig.; Carlos Martínez Gorriarán, Casa, Provincia y Rey..., p. 25; Javier Pérez Núñez, La diputación foral de Vizcaya, Centro de Estudios Constitucionales, Madrid, 1997, p. 10.

41 Manuel de Larramendi, Corografía..., p. 159.

42 Javier Corcuera, Orígenes, ideología y organización del nacionalismo vasco, 18761904, Siglo XXI, Madrid, 1979, p. 362.

43 Manuel de Larramendi, Corografía..., p. 140. 
connotaciones cristianas negativas como el sufrimiento, la penitencia o el sacrificio. Como ha explicado William Sewell para el caso francés, el trabajo manual, considerado como actividad física envilecedora, era además un elemento de jerarquización y posicionamiento social ${ }^{44}$. Frente a los individuos de los estratos sociales más bajos que debían «ganarse el pan» con el trabajo de sus manos, la nobleza y el clero, no tenían la necesidad de laborar, teniendo así la oportunidad de dedicarse a actividades relativas al ejercicio del intelecto, positivamente valoradas dentro de este esquema social.

Sin embargo, en el imaginario de Larramendi la relación entre los «oficios humildes» y la «nobleza» no estuvo reñida. El concepto de hidalguía no entraba en contradicción con el desempeño de labores manuales, ya fueran estas más o menos físicas. Más bien al contrario, eran dos dimensiones de la identidad guipuzcoana que aparecían íntimamente ligadas:

«Guipúzcoa [...] emplea en los oficios humildes de las repúblicas a guipuzcoanos, todos nobles e hidalgos de sangre: zapateros, sastres, herreros, carpinteros, sombrereros, jornaleros, labradores, tratantes, mercaderes en menudo y grueso, y otros oficios más o menos humildes, todos son de nobles, siendo guipuzcoanos $»^{45}$.

Larramendi, no obstante, no pretendía defender una universal igualdad. Trataba de ofrecer una redefinición del trabajo manual que superara las tradicionales visiones del Antiguo Régimen. Pretendía así resolver la contradicción entre nobleza y trabajo envilecedor y generar un nuevo significado ennoblecido del trabajo de sus guipuzcoanos/as. Precisamente porque era desempeñado por los habitantes de la provincia, era también un noble y varonil trabajo.

Lo más destacable de esta singular revalorización del trabajo es que fue acompañada de una reelaboración de la diferencia sexual y de la construcción de una muy particular visión del género y de la corporalidad construidas a partir de conceptos y argumentos típicos de la «querella» y de los debates dieciochescos sobre la feminidad y la masculinidad. Al relato de la Gipuzkoa foral le acompañó la construcción de un cuerpo gui-

${ }^{44}$ William H. Sewell, Trabajo y revolución en Francia: el lenguaje del movimiento obrero desde el Antiguo Régimen hasta 1848, Taurus, Madrid, 1992, pp 45-50.

${ }^{45}$ Manuel de Larramendi, Corografía..., p. 136. 
puzcoano ${ }^{46}$, un ideal que representaba los valores físicos y morales de la varonil Gipuzkoa. Como bien han mostrado autores/as como Foucault, Scott o Butler, el género no es el correlato o traducción cultural de una entidad biológica, del cuerpo sexuado. Sabemos que, al igual que el género, también el sexo y el cuerpo son complejos sistemas de atribuciones de significados. En definitiva, que son construidos a partir del vuelco de un sinfín de asunciones sociales y culturales sobre el género ${ }^{47}$. Se trata pues de una modelación de cuerpos sexuados masculinos y femeninos a partir de y en relación a los valores políticos, sociales y culturales que se presuponen a los géneros. El sexo, el género y el deseo guardan una coherencia absoluta dentro de estos marcos normativos, que generan a su vez límites, no-lugares para lo ininteligible, para lo que no tiene cabida dentro de las coordenadas de la «normalidad».

En el caso de Larramendi, la diferencia sexual y el cuerpo guipuzcoano - el de los hombres, pero de forma especialmente efusiva, el de las mujeres - , fueron construidos en relación al discurso sobre los quehaceres de la vida rural, y se manifiesta de forma importante a través de sus abundantes descripciones de los usos indumentarios o en las pormenorizadas explicaciones de los bailes tradicionales. Mediante estos discursos, el autor generó poderosas imágenes corporales, como se aprecia en el siguiente fragmento:

«de estatura regular, bien agestados, blancos, aun los que todo el año sufren los ardores del sol y las inclemencias del tiempo, como son los labradores y caseros $[\ldots]$ y bien pobladas cabeza y barba. Son de cabeza tan sana, dura y fuerte, que apenas hay herida de muerte en la cabeza [...] Tienen cuerpos de gran resistencia contra los fríos, hielos, nieves, cierzos frigidísimos [...] En los pueblos formados, las gentes de calle son de más delicadeza» ${ }^{4}$.

46 Como elemento comparativo, para un análisis sobre la relevancia de la dimensión corporal y emocional en la construcción de las identidades nacionales véanse José Javier Díaz Freire, «El cuerpo de Aitor: emoción y discurso en la creación de la comunidad nacional vasca», Historia Social, 40, 2001, pp. 79-96 y «Cuerpos en conflicto. La construcción de la identidad y la diferencia en el País Vasco a finales del siglo XIX», en Mary Nash y Diana Marre (eds.), El desafío de la diferencia. Representaciones culturales e identidades de género, raza y clase, UPV/EHU, Bilbao, 2003, pp. 61-94.

47 Joan W. Scott, «Unanswered questions», The American Historical Review, vol. 113, 5, 2008, pp. 1422-1430, p. 1424.

48 Manuel de Larramendi, Corografía..., p. 187. 
Larramendi creó, en contraste con este ideal normativo, sus propios abyectos. Lo «afeminado», en el sentido de endeble o poco robusto, representaba lo opuesto a la fortaleza guipuzcoana:

«No se ven en Guipúzcoa hombres de cuerpos feos, monstruosos, contrahechos y de semblantes brutos, como en otros reinos. Son ágiles, vivos y prontos, fuertes y robustos, y todos con caras de hombres - que no degeneran en carillas de mujer, o por mal comidos, o por haber nacido endebles, o por educación afeminada $»^{49}$.

Configuró así un tipo corporal en el que los valores físicos por excelencia eran aquellos relacionados con la fortaleza, dureza y fiereza físicas, necesarios en una Gipuzkoa que, a sus ojos, se debatía entre las inclemencias a las que se enfrentaban en el entorno rural y pesquero, y las encarnizadas batallas contra sus numerosos enemigos. Se trataba pues de un modelo corporal varonil, marcado por la robustez y la hombría que en las sociedades de la Edad Media y del Antiguo Régimen se atribuían a lo «masculino» ${ }^{50}$. Lo que, desde una perspectiva contemporánea, puede sorprender es que también las mujeres correspondían a este canon corporal viril:

«Las mujeres en Guipúzcoa son las más hermosas que hay en toda España; de bellísimo color, bien apuestas, rollizas, fuertes, ágiles y sanas; de pocos melindres y hazañerías, de gran despejo, que bajan y suben a sus caserías y montes con el mismo aire y vigor que si no hubiera cuesta. Son más robustas y de más aguante que los hombres en llevar y traer cargas pesadísimas sobre su cabeza de un lugar a otro, distante tal vez tres o cuatro leguas» ${ }^{51}$.

Contrasta radicalmente, además, con el modelo de feminidad que la Ilustración comenzaría a prescribir en aquel momento y, que como ha sido extensamente analizado, promovió, en líneas generales, una feminidad ligada a valores como la delicadeza, la sensibilidad y la domesticidad. Y todo ello resultaría asociado a una función social que sería de vital importancia dentro de las nuevas sociedades burguesas, la maternidad.

\footnotetext{
49 Ibidem, p. 187.

${ }^{50}$ George Mosse, The Image of Man. The creation of Modern Masculinity, Oxford University Press, Oxford, 1996, p. 17.

51 Manuel de Larramendi, Corografía..., p. 188.
} 
En su obra Larramendi dejó en un segundo plano estos aspectos para vincular a las mujeres a actividades relacionadas con la vida y el trabajo en el caserío, incluso relacionadas con el desempeño de las armas en tiempos de guerra. Como expresa el siguiente fragmento, el papel otorgado a las mujeres dentro de la estructura familiar y los quehaceres correspondientes, distaba profundamente de la hogareña estampa ilustrada. En sus descripciones, mientras los hombres trabajaban en el campo o la herrería, las mujeres ayudaban con fuerza y vigor en lo que fuera menester:

«Y ¿qué hacen a todo esto las mujeres? En las caserías ayudan varonilmente a sus maridos, cavando, layando, sembrando y todas las demás faenas, y aun conduciendo carros cargados, como boyerizas. En los pueblos sembrando linos por sí mismas y prosiguiendo tantos trabajos como son necesarios hasta reducirlos a copos [...] Otras muchísimas son jornaleras en el tiempo de cosechas del trigo y de su trillamiento en las eras $[\ldots]$ mujeres son las que ayudan a descargarlos y las que llevan la manzana en cestas a los lagares y sacan después las sidra de la finia y la trasiegan a las cubas, que es faena de muchos días» ${ }^{52}$.

El duro trabajo físico realizado por mujeres no solo no era criticado por ser nocivo para la naturaleza femenina y un cuerpo deseables. Más bien al contrario, las consideraba labores altamente estimables. Como ha sido abundantemente analizado, el trabajo productivo femenino era común tanto en el ámbito rural como en el costero de las provincias vascas, bien como complemento a las labores desempeñadas por los hombres, o bien como labores que se realizaban ante la coyuntural ausencia de varones durante periodos bélicos o por su desempeño de actividades relacionadas con la $\operatorname{mar}^{53}$. La Gipuzkoa de los y las baserritarras, gentes del

52 Ibidem, p. 203.

53 Véanse José Antonio Azpiazu, Mujeres vascas. Sumisión y poder, Haranburu, San Sebastián, 1995, pp. 83-146; John Lawrence, «Spanish Women in the Resistance to Napoleon, 1808-1814», en Victoria Lorée y Pamela Radcliff (eds.), Constructing Spanish Womanhood. Female Identity in Modern Spain, State University of New York Press, Albany, pp. 259-282, pp. 275-276; Lola Valverde, «Contexto social y situación de la mujer vasca en el Antiguo Régimen», en Emakumea Euskal Herriko Historian/La Mujer en la Historia de Euskal Herria, IPES, Bilbao, 1988, pp. 35-45 y de la misma autora Familia, ezkontzak eta genero-harremanak Azpeitian, Azpeitiko Udala, Azpeitia, 2011, pp. 173-221. Para el ámbito costero véase M. J Jesús Fernández Fonseca y Ana Isabel Prado Antúnez, «Roles femeninos en la Bizkaia del siglo XIX: aproximación a la situación de la mujer en el mundo laboral en ámbitos pesqueros urbanos», Itsas Memoria, 3, 2000, pp. 277-287. 
campo, era una comunidad marcada por la fuerza de lo masculino, tanto en su aspecto físico como por su virtud moral, y a este debían responder todos sus habitantes, mujeres incluidas.

La virilidad de las mujeres no solo se manifestaba en estas descripciones del mundo rural, sino también en el ánimo belicoso que se atribuía a los guipuzcoanos. Esto así, también en la pericia militar destacaban las mujeres que compartieron con los hombres el «ethos guerrero ${ }^{54}$ característico de su nobleza. Así, afirmaba Larramendi que:

«aunque se niegue en el Thermodoonte, donde puso su habitación la antigüedad, ya es notorio a todos que, en la partida del valor Marcial hubo Amazonas Guipuzcoanas, que supieron manejar las armas, jugar el azero, y defender la brecha, muriendo y matando con horrible estrago de sus enemigos» ${ }^{55}$.

El recurso al amazonismo no fue exclusivo de este autor, sino que formó parte del argumentario de muchos otros que durante el XVIII lo utilizaron para alabar o menospreciar a las mujeres ${ }^{56}$. Aunque más que por su veracidad histórica fue esgrimido como recurso literario, resulta de gran utilidad porque nos permite observar el deslizamiento, o más bien práctica disolución, de la ecuación mujer-feminidad vs hombre-masculinidad característica de estas visiones. La construcción de la diferencia sexual larramendiana incorporó en ella elementos que escapan a la arquitectura del sexo-género arriba descrita. El marco discursivo desde el que escribía respondía a una codificación social de la relación entre el género y el cuerpo que trascendía el dimorfismo biologicista que otorgaba la propiedad exclusiva de la masculinidad a los hombres y el de la feminidad a las mujeres. Se inscribía en aquel régimen de verdad en el que la identidad de las personas no venía ineludiblemente prefigurada por su sexo biológico.

Elaboró así un ideal corporal varonil al que debían responder no solo los hombres sino, de forma especial, las mujeres ${ }^{57}$. El ensalzamiento de la virilidad fue un recurso que compartieron otros autores de la época, in-

${ }^{54}$ Carlos Martínez Gorriarán, Casa, Provincia y Rey..., p. 251.

55 Manuel de Larramendi, El Imposible Vencido, Amigos del Libro Vasco, Echevarri, 1988, p. 73.

56 Oliva Blanco, La polémica feminista..., p. 77.

57 Véanse José Javier Díaz Freire, «Cuerpos en conflicto...» y Nerea Aresti, «De heroínas viriles...». 
cluso bien avanzado el siglo, tal y como muestran las creaciones de catálogos de mujeres fuertes y celebres en «letras, armas y gobierno», tanto en España como en Europa ${ }^{58}$. Estas representaciones literarias o iconográficas, que exaltaban valores característicos de las elites aristocráticas, se oponían al ideal de feminidad burgués que se estaba forjando y que devendría mayoritario posteriormente. En el caso de Larramendi, esta virilización adquiría ciertos matices diferenciados ya que contribuía además a ennoblecer toda una comunidad singular, a todos sus hombres y sus mujeres.

\section{La vestimenta como expresión de superioridad moral: las caseras de tocado blanco y rosario de plata}

También el discurso sobre el atuendo del cuerpo guipuzcoano resultó ser importante elemento de construcción identitaria, y no solo en lo que al género se refiere, sino también a la articulación entre la singularidad comunitaria, la clase y la identidad religiosa. La preocupación de Larramendi por las consecuencias nocivas que el lujo y la introducción de las nuevas modas en auge durante el XVIII tenían en el modelo de feminidad guipuzcoano, entroncó con un debate en torno al lujo y sus implicaciones económicas, sociales y morales. Como ha analizado Mónica Bolufer, esta polémica resulta especialmente interesante en tanto que arroja luz sobre los modelos de género que operaban desde las distintas posturas sociales y políticas en conflicto ${ }^{59}$. Las críticas ilustradas al lujo aristocrático convivieron con el discurso sobre el nuevo confort burgués de los ámbitos más ilustrados, que se enfrentaban, a su vez, a las encendidas censuras de los moralistas, defensores de lo tradicional. Estas últimas apelaban a una supuesta higiene moral que subyacía a la buena presencia y austeridad de los atuendos tradicionales ${ }^{60}$. Esta fue

58 Mónica Bolufer, «Galería de «mujeres ilustres»...», p. 191.

59 Mónica Bolufer, «La imagen de las mujeres en la polémica sobre el lujo (siglo XVIII)», en Cinta Canterla (coord.), De la Ilustración al Romanticismo. Cádiz, América y Europa ante la Modernidad. La mujer en los siglos XVIII y XIX, Universidad de Cádiz, Cádiz, 1993, pp. 175-186, p. 179.

${ }^{60}$ Mónica Bolufer, «Cambio dinástico ¿Revolución de las costumbres? La percepción de moralistas, ilustrados y viajeros», en Eliseo Serrano (ed.), Felipe V y su tiempo..., pp. 585-630, p. 586. 
la postura de Larramendi. En el discurso de este último, además, la defensa del buen vestir de sus convecinos, en su dimensión estética, pero íntimamente ligada a su dimensión moral, funcionaba principalmente como mecanismo generador de la diferencia con «lo otro», lo sucio, encarnado en lo castellano:

«Todos los guipuzcoanos, ellos y ellas, son muy inclinados a ir bien vestidos y no aparecer en las calles, plazas e iglesias, ni entre gentes, sino muy limpios y muy decentes. Nunca se ve en Guipúzcoa tanto capipardo, braquirroto, cascarriero, arlote, desgreñado, mugriento, desparrajado, asqueroso y sucio como se encuentran en los pueblos de Castilla y otros reinos» ${ }^{61}$.

La distancia y diferencia con esos otros pueblos quedaba definida a través del vestido. Los escritos de Larramendi, no obstante, muestran un especial interés por el cuerpo vestido femenino. El atuendo de las mujeres guipuzcoanas había sido, y debía seguir siendo, aquel que se caracterizara por la sobriedad de sus formas, que se materializaba en la preferencia por los ropajes blancos, que con pasmosa minuciosidad se afanó en describir. La característica fundamental del vestido femenino era la limpieza: «Todas las guipuzcoanas son de una inclinación predominante a la ropa blanca, y en tenerla mucha y de buena tienen su mayor gusto y cuidado. Bajan de sus caserías con su ajuar en la cabeza, limpia cara y manos como una plata» ${ }^{62}$.

Descripciones como esta pueden considerarse el ejemplo de la construcción de la excelencia de la apariencia del cuerpo guipuzcoano. Su preocupación por la decencia y corrección de la exterioridad corporal era propia de un contexto social europeo, el del tránsito entre los siglos XVII y XVIII que, como explicó Chartier, se caracterizó por los cambios en las normas sobre la civilidad y las conductas sociales y costumbres aceptables y no aceptables, así como por la intensificación de su control, que hicieron de la apariencia y modelación del cuerpo su principal foco de atención ${ }^{63}$. En España, esta modificación de las cos-

${ }_{61}$ Manuel de Larramendi, Corografía..., p. 216.

62 Ibidem, p. 219

${ }^{63}$ Roger Chartier, «Introducción. Formas de la privatización», en Phillippe Ariès y Georges Duby (dirs.), Historia de la Vida Privada. Del Renacimiento a la Ilustración, Taurus, Madrid,1989, pp. 165-167, p. 165. 
tumbres estuvo en cierta manera condicionada por la implantación de los Borbones, que introdujeron novedades, importadas de Francia e Italia, en los hábitos y comportamientos de la corte, pero que tuvieron su reflejo en el conjunto de la sociedad ${ }^{64}$. En este contexto de paulatinas reformas, Larramendi quiso destacar la decencia y calidad del atuendo guipuzcoano tradicional para que hiciera justicia a la nobleza de sangre y de virtud de sus habitantes. Como dijera Norbert Elias, se trataría de la voluntad de «la representación del rango a través de la forma» ${ }^{65}$, que en el caso que nos ocupa, se traduciría en que los códigos indumentarios tradicionales representaban la excelencia del ideal guipuzcoano, tanto en su adecuación a la singularidad provincial, como a la ley cristiana. Para esta operación discursiva resultó instrumental, de nuevo, acudir a la dignificación de la pobreza, ya que, como aclaraba el autor:

«No es, pues, señal de riqueza y mucho dinero el que la gente de Guipúzcoa, aun la menuda y vulgar, salga tan bien vestida en las fiestas y funciones; solamente es señal de ser gente aseada, limpia y amiga de bien parecer, y que tiene habilidad de lucirlo con su pobreza» ${ }^{66}$.

Cabe destacar, además, la importancia que Larramendi otorgó no solo a ser nobles, sino también a parecerlo. El vestido del cuerpo cumplía una función significante indispensable dentro de la organización de la comunidad y en este caso tenía la función de significar la calidad moral de sus portadores, y especialmente, el de sus portadoras. Como ha apuntado Jaques Revel, el vestido, así como los gestos corporales o los comportamientos pueden considerarse «signos hablantes [que] son la base de un léxico del reconocimiento» ${ }^{67}$. Tanto era así que la importancia de mostrarse vestidas con arreglo a los criterios de decencia se imponía sobre otro tipo de necesidades:

«Pero, ¿cómo se hace este milagro en pobres labradoras y caseras? Quitándoselo de la boca y ahorrando cuanto pueden en el comer y be-

\footnotetext{
64 Mónica Bolufer, «Cambio dinástico ¿Revolución...», p. 589.

65 Roger Chartier, «Introducción...», p. 165.

66 Manuel de Larramendi, Corografía..., p. 221.

67 Jaques Revel, «Los usos de la civilidad. Formas de la privatización», en Phillippe Ariès y Georges Duby (dirs.), Historia de la Vida Privada..., pp. 169-209, p. 170.
} 
ber. Yo sé que en otras partes hombres y mujeres de labranza y oficiales están más entregados a su vientre y a comer y beber, y andan arlotes y mal vestidos...» ${ }^{68}$.

En la Gipuzkoa de mediados del siglo XVIII, el lugar donde la exterioridad se convertía en uno de los principales elementos de transmisión y comunicación era el espacio del ritual social por antonomasia, la iglesia. Esto así, en la Corografía se centró en ensalzar el buen hacer de las caseras que, con poco dinero y a base de ahorro, eran capaces de vestir con intachable decencia para bajar de sus caseríos a escuchar misa:

«...cubren su cabeza con el tocado blanco como la nieve, y gastan prolijidad en acomodarlo, ya de un modo, ya de otro, y siempre con mucho aire. No hay casera casada que ande con la cabeza descubierta, aunque si las casaderas [...] Vuelven otra vez al cuello a cubrirlo con una corbata limpísima de gasa y encajes, que con alfileres aquí y alfileres allí la prenden con notable gusto y proporción y quedan modestísimamente cubiertas $[\ldots]$ En el punto de salir a la calle y a la iglesia [...] toman su rosario en la mano, y es muy común que esté engarzado en plata, y así andan en la calle y están en la iglesia» ${ }^{69}$.

Esta inmaculada exterioridad del cuerpo de las mujeres guipuzcoanas se construyó en oposición a la opulencia de la que se hacía gala en los espacios cortesanos ${ }^{70}$. Su crítica al estamento nobiliario no solo se dejó ver en el discurso sobre el trabajo sino, de forma especialmente furibunda, en la denuncia de la indecencia de los usos indumentarios, en los que observaba la capacidad de pervertir aquel buen vestir característico de la provincia. Y así había comenzado a suceder entre los jaunchos y andiquesas, es decir, en la clase los propietarios rurales, aquellos que debían vertebrar y guiar el buen funcionamiento del gran mayorazgo guipuzcoano a través del cuidado de sus solares ${ }^{71}$. La crítica de Larramendi se articulaba sobre dos claros antagonismos que hacían peligrar la continuidad del divino so-

68 Manuel de Larramendi, Corografía..., p. 216.

${ }^{69}$ Ibidem, p. 214.

70 Véase Carmen Martín Gaite, Usos amorosos del dieciocho en España, Anagrama, Barcelona, 1987.

${ }^{71}$ En «Manuel de Larramendi: la particular historia de Guipúzcoa» Pablo Fernández Albaladejo explica que «Necesariamente el proyecto de Larramendi es un proyecto interclasista, cimentado sobre la defensa de un grupo social que considera sustentador del equilibrio interno que debe reinar en la Provincia», p. 153. 
lar guipuzcoano: la oposición entre lo viejo y lo nuevo, entre un pasado primitivo, siempre mejor, y el nuevo y «loco» futuro, y la oposición entre el mundo rural y el urbano, en un contexto social y económico en el que este último comenzaba a adquirir mayor protagonismo a consecuencia del paulatino desarrollo de la actividad mercantil. El abandono de un austero modo de vida relacionado con el trabajo en el campo o en la herrería, por la vida en las villas o ciudades, había llevado a los andiquis de la provincia a imitar las modas y costumbres foráneas, venidas de las cortes francesa y castellana, que ponían en peligro de disolución el tradicional modo de vida:

«Yo me acuerdo cuando las caseras se vestían sólidamente y con decencia, sí, pero sin tantos melindres y piezas superfluas, de que se visten hoy. Estas modas son nuevas, y las han dado y dan ejemplo los caballeros y señoras. Ellos con monos unos de otros, y todos lo son de franceses y castellanos [...] De pies a cabeza se han de vestir a la moda de Francia [...] esto han aprendido nuestros jaunchos, como otros españoles, que aprenden todas las nulidades de Francia, y no hacen caso de tanto bueno que pudieran aprender y comunicarlo a España» ${ }^{72}$.

El juicio más severo, no obstante, se lo dedicaba el jesuita a las andiquesas de la provincia, «arruinadoras de sus casas y haciendas» ${ }^{73}$, a las que describió casi como auténticas cortesanas, amantes del lujo, el artificio, el exceso y la ostentación, que sucumbían ante las modas venidas de fuera: «Si en Castilla aderezos preciosos, joyas, brazaletes de tumbaga, anillos de diamantes, en oro, helos aquí en Guipúzcoa. Si en Castilla corsés y escotes, tontillos de ballena, de hierro, helos aquí en Guipúzcoa...» ${ }^{74}$. Se lamentaba de que muchas eran ya las mujeres que seguían estas modas: «Sobradas son para el escándalo, para mis quejas e impaciencias, y para ruina de sus casas. Tampoco me digan que no andan tan descubiertas, descolladas, despechonadas, inmodestas,

72 Manuel de Larramendi, Corografía..., p. 221.

73 Ibidem, p. 222. Como han explicado Oliva Blanco en La polémica feminista...y Mónica Bolufer en «La imagen de las mujeres...», uno de los argumentos que tanto los pensadores más conservadores como los ilustrados esgrimieron en contra del gasto desmedido, fue el que defendía que el despilfarro por parte de las mujeres podía incluso llegar a ser perjudicial para la economía del país.

74 Manuel de Larramendi, Corografía..., p. 223. 
indecentes» ${ }^{75}$. Y se cuestionaba «¿con qué fin toda esa faena y ocupación? ¿Es con el fin de agradar a Dios y los ángeles y santos? ¿Es con el fin de parecer buenas cristianas? Que se respondan ellas mismas...» ${ }^{76}$. En este sentido, podemos afirmar que, como clérigo jesuita, Larramendi era deudor de toda una tradición moralista católica que concebía el gusto por las apariencias como un defecto característico de la feminidad, que conectaba a las mujeres con el pecado y las alejaba del los preceptos del cristianismo ${ }^{77}$.

Pero esta valoración negativa de la feminidad no se contentaba con esgrimir argumentos de corte moralista. Bolufer ha apuntado que las posturas más tradicionalistas y conservadoras se caracterizaron, además, por criticar «las pretensiones de ascenso a través de la emulación de comportamientos suntuarios ${ }^{78}$. Es decir, guardaban también una importante crítica de carácter social y económico. Tal y como harían muchos otros autores, también Larramendi dio cuenta del peligro que existía en Gipuzkoa en que las mujeres pertenecientes a las clases más humildes trataran de imitar a aquellas de las esferas más altas. Así lo expresa en las siguientes palabras, en las que criticó, por un lado, a las que siendo simples criadas pretendían asemejarse a sus señoras, y por otro, a las propias damas de la alta sociedad guipuzcoana que daban mal ejemplo a las mujeres de origen humilde:

«Este mal ejemplo de las damas y señoras es el que siguen ya las criadas mayores y menores y las mozas de la calle. Cincuenta años ha que apenas se vestían las amas y andiquesas de Guipúzcoa como se visten hoy las nescames [criadas] los días de fiesta [...] Con estas y otras piezas se prenden las que el día siguiente saldrán descalzas a la

75 Ibidem, p. 223.

76 Ibidem, p. 222.

77 Véanse a este respecto María Ruiz Ortiz, «Pecados femeninos y vida privada: discursos sobre la conciencia y la vida cotidiana en la España Moderna (ss. XVI-XVIII)», Cuadernos de Historia Moderna, 39, 2014, pp. 59-75; Isabel Morant, «Hombres y mujeres en el discurso de los moralistas. Funciones y relaciones», en Isabel Morant (dir.) y M. Ortega, A. Lavrin y P. Pérez (coord.), Historia de las Mujeres en España y América Latina II: El Mundo Moderno, Cátedra, Madrid, 2005, pp. 27-61; M. ángeles Hernández, «La imagen de la mujer en la literatura moral y religiosa de los siglos XVI y XVII», Norba. Revista de Historia, 8-9, 1987-1988, pp. 175-188.

78 Mónica Bolufer, «La imagen de las mujeres...», p. 178. 
calle. Y apenas hay una de éstas que, aunque haya servido muchos años, no tenga cobrados todos sus salarios y empleados en vestirse y engalanarse» ${ }^{79}$.

Mediante estas palabras, Larramendi no intentaba tanto hacer prevalecer la desigualdad social que existía entre las andiquesas y las nescames, sino, más bien, trataba de igualarlas a todas bajo un mismo código moral y de decencia, significado a través de una apariencia común, en tanto que guipuzcoanas, desde la más rica, hasta la más pobre. Quería, en definitiva, que tanto unas como otras se parecieran más a las caseras de tocado blanco y rosario de plata que eran representantes del arquetipo moral y corporal guipuzcoano. Esta noble virtud guipuzcoana igualaba, dentro de los límites jerárquicos característicos de su pensamiento social y religioso interclasista, a todas las mujeres de la provincia haciéndolas excepcionales. Era, en definitiva, lo que las diferenciaba del resto de mujeres de otras provincias y reinos. El de Larramendi no fue un discurso que pretendiera juzgar ni categorizar a todos los miembros del sexo femenino bajo un universal «mujeres». Como representante de la mentalidad misógina y jerárquica de la tradición eclesiástica, consideraba que no todas podían ser iguales, ni socialmente ni en su virtud. Únicamente en el caso de las excepcionales y varoniles mujeres guipuzcoanas se podía, y debía, obrar el milagro en el que incluso las más humildes caseras se distinguieran sobre el resto por trascender todos los defectos atribuibles a su sexo y a su condición social. La originalidad del pensamiento de este autor radica en que también en la cuestión sobre la moralidad de los atuendos femeninos la importancia del ingrediente provincial, de la identidad comunitaria, eclipsó al resto de factores, tanto a las implicaciones de género como a las de clase o rango social.

79 Manuel de Larramendi, Corografía..., pp. 221 y sig. Para un análisis sobre el fenómeno de la petrimería véanse: Rebecca Haidt, Women, work and clothing in Eighteenth-century Spain, Voltaire Foundation, University of Oxford, Oxford, 2011 y «A well-dressed woman who will not work: Petimetras, Economics and Eighteenth-Century Fashion Plates», Revista Canadiense de Estudios Hispánicos, vol. 28, 1, 2003, pp. 137157. 


\section{Entre el rigor religioso y el baile en la plaza pública: la construcción del deseo aceptable}

Un tercer espacio discursivo que definió la singularidad comunitaria en relación con el género y la sexualidad, es el referido a las danzas tradicionales guipuzcoanas. La apología larramendiana de las danzas debe ser situada en el contexto de disputa dialéctica más amplia que el autor mantuvo con su correligionario Sebastián Mendiburu (1708-1782) y se enmarca dentro de un debate de largo recorrido histórico entre los miembros de la Compañía de Jesús y otras órdenes que se alargaría en el tiempo hasta bien entrado el siglo $\mathrm{XIX}^{80}$. El argumento principal que esgrimían aquellos que se oponían al baile era que el contacto entre hombres y mujeres incitaba inevitablemente al pecado y que la muestra pública, e impúdica, de los ejercicios físicos no se adecuaba a las normas de decencia y virtud cristiana. Fueron precisamente estos los argumentos que Larramendi trató de rebatir, dedicando para ello no pocas páginas. El tema era importante porque estaba en juego la virtud de los/las guipuzcoanos/as.

La defensa de las danzas comenzaba con un minucioso repaso de la literatura bíblica y clásica en torno a la cuestión, tras la que el autor concluía que los argumentos a favor de la moralidad de los bailes se imponían sobre los motivos para su censura. No obstante, es necesario remarcar que a Larramendi únicamente le interesaba defender los bailes de «tamboril» guipuzcoano, ya que «De las otras danzas [...] no quiero decir nada, porque aunque se hacen también en algunos lugares de Guipúzcoa, pero no son propias de este país, y han venido de fuera, y no tienen los defensivos de nuestras danzas» ${ }^{81}$. Es decir, el elemento dignificador y moralizador del baile era su singularidad provincial y tradicional, virtuosa por definición. Por ello, no apreciaba ningún «peligro mortal» en los bailes de las plazas de los pueblos guipuzcoanos, ni siquiera en aquellos en los que tanto hombres como mujeres participaban conjuntamente:

«Pregunto: ¿las hacen malas el que dancen los hombres en la plaza? No. ¿El que la dancen allí las mujeres? Tampoco. ¿El que dancen hombres con mujeres? Dirán que sí, y que en eso está la maldad y el escándalo. Pero así en cerro y en esa generalidad dirán muy mal. ¿Pues acaso

80 Véase Joxemiel Bidador, Dantzaren Erreforma Euskal Herrian, Ayuntamiento de Bilbao, Bilbao, 2005.

81 Manuel de Larramendi, Corografía..., p. 264.

Historia Contemporánea 52: 9-42 
no pueden danzar hombres con mujeres con modestia y con decencia? ¿Es imposible que dancen hombres con mujeres sin tener una intención torcida, malvada, deshonesta?» ${ }^{82}$.

Como sus correligionarios, Larramendi no ignoraba «los peligros» de la carne que la proximidad entre los cuerpos podría suscitar «Pólvora, yesca y estopa es el mozo junto a la moza, ambos alegres y danzando». No obstante, la incorporación naturalizada de la vigilancia divina hacía que el peligro se desvaneciera, ya que «es pólvora mojada y que le está lloviendo Dios desde el cielo con ilustraciones e inspiraciones que no dejan prender el fuego de lascivia, antes bien la apagan y anegan» ${ }^{83}$.

Como en el caso de muchos otros dilemas morales, el vituperio de los contrarios al baile había puesto en el sexo femenino su punto de mira. Larramendi, sin embargo, tal y como haría en el caso del atuendo, también en el baile anteponía la calidad moral de las guipuzcoanas a sus prejuicios misóginos, no incompatibles con la defensa moral de sus paisanos $-\mathrm{y}$ paisanas - :

«han reparado en que van más bien vestidas que nunca, reparen y digan también con cuánto recato van vestidas, cuán decentes y modestas, cuán hundidos los pechos, cuán cubiertos los hombros, cuán velados los cuellos y son indicio de su vergüenza, de su honestidad y de que están muy lejos de salir con la mala intención de provocar; y sería un juicio temerario atribuirlas las malas intenciones» ${ }^{84}$.

¿Cuál era la clave fundamental que hacía que el baile entre mujeres y hombres no fuese pecaminoso, sino más bien una actividad tradicional merecedora de respeto y admiración, incluso en las ocasiones en las que las mujeres se permitían saltar y brincar ante la atenta mirada de sus convecinos/as? El autor respondió a esta cuestión de manera contundente:

«Son guipuzcoanos los que danzan, cristianos y católicos por la gracia de Dios, [...] Están instruidos por sus padres, por los predicadores, por los confesores, que son pecados los malos deseos de la carne y todo pensamiento consentido contra la castidad. Se confiesan de ellos [...] Saben que por un mal deseo y por una acción deshonesta se pierde el

\footnotetext{
82 Ibidem, p. 243.

83 Ibidem, p. 269.

${ }^{84}$ Ibidem, p. 262.
} 
cielo que esperan, para siempre, y se condena a un infierno y en él el fuego eterno» ${ }^{85}$.

Encontramos en las palabras de Larramendi el ejemplo paradigmático de lo que Foucault llamaría el «animal de confesión», o el ser humano entendido como enclaustrado en un alma que acusa al cuerpo ante sus tentaciones $^{86}$. Se trata de uno de los mecanismos de control y de construcción de la identidad sexual más recurrentes a lo largo de la historia. Todos los agentes sociales participaban de ese régimen de la confesión «que fue y sigue siendo hoy la matriz general que rige la producción del discurso verídico sobre el sexo» ${ }^{87}$. Pero la expresión más sofisticada del ejercicio del poder y la coacción es aquella que cada individuo ejerce sobre sí mismo cuando la norma ha sido interiorizada y el alma se ha convertido en la cárcel del cuerpo y no al contrario. Esta disciplina interna, modelada a través de la coerción exterior, convertía las danzas en un «divertimento inocente» a los ojos de Larramendi. Gracias a la instrucción y a la confesión, «gracia exterior e interior» quedaban intactas en las coreografías del baile de tamboril de guipuzcoano.

Descubrimos, además, que siempre que estuviera sujeto al escrutinio público y coreografiado a partir de criterios «de decencia», el baile en la plaza pública era un ámbito privilegiado para la socialización entre los sexos:

«Que las mozas salgan al baile más bien vestidas que nunca, ¿por qué lado será provocativo? Así van a las bodas, así van a las romerías, así van a toros y otras fiestas; y ¿Quién ha dicho que, sin más ni más, el ir así vestidas es malo y provocativo? Es que van a ser vistas; y que los hombres, viéndolas, se agradan en ellas. Claro está que van a ser vistas, y bien vestidas, porque no van ni irían a danzar con topos y ciegos; y saliendo a la plaza pública, no quieren que las tengan por sucias, arlotas, andrajosas $[\ldots]$ ¿No puede una moza ser del agrado de un mozo sin pecado? ¿Y no puede caer un hombre en gracia de una mujer dentro de la decencia y de la modestia? Jesucristo dijo, dando lecciones a sus

85 Ibidem, p. 267.

${ }^{86}$ Michel Foucault, Historia de la sexualidad, I. La voluntad de saber, Siglo XXI, Madrid, 1980 , p. 36.

87 Ibidem, p.39. 
Apóstoles, que era pecado mirar a una mujer con mal deseo y lasciva intención, pero no dijo que era pecado mirar y ver mujeres, ni en éstas mirar a los hombres, sin ese mal deseo ${ }^{88}$.

De su defensa de las danzas emerge, como observamos en estas palabras, otro de los aspectos fundamentales de su obra: el modo en el que se construyeron el deseo y la identidad sexual guipuzcoanas junto con el control y sanción pública de los deseos y las pasiones carnales en las relaciones entre los sexos. En otras palabras, este fue un ejercicio de construir la frontera infranqueable entre el deseo aceptable y no aceptable para sus intachables feligreses. La necesidad no tanto de sancionar toda expresión de deseo, sino de definir y delimitar, de generar un conocimiento público, un espacio de saber-poder, en torno a aquellas actividades en la que ambos sexos podían participar de forma virtuosa resultaba indispensable. No en vano, Larramendi dirigió sus críticas a los predicadores, principales instructores de los guipuzcoanos, principales generadores de conocimiento o desconocimiento, como en este caso, que mediante su condena de las danzas estaban dirigiendo a los jóvenes al pecado, tal y como se lamenta en las siguientes palabras:

«Si de este hecho, que es certísimo, estuvieran instruidos los predicadores, habían de hacer escrúpulo de condenar la danzas de Guipúzcoa, restringidas, como están, porque son el medio único para evitar en gran parte las maldades e infamias de mozos y mozas en despoblado y sin testigos» ${ }^{89}$.

Advertimos que, en este sentido, Larramendi se mostró profundamente moderno. Tanto así que, sin saberlo, compartió opinión con algunos hijos anti-clericales de la Ilustración que criticaron a los misioneros vascos herederos del espíritu contrarreformista que comenzó a ser efectivo a partir del siglo XVIII en las provincias vascas ${ }^{90}$. Los ilustrados les acusaban de haber pervertido las sanas e inocentes costumbres de las jóvenes muchachas con sus moralistas improperios, obligándolas a relacionarse con el sexo opuesto en lugares ocultos a la sanción pública. Así

${ }^{88}$ Manuel de Larramendi, Corografía..., p. 262 y sig.

89 Ibidem, p. 277.

90 Belen Altuna, «La idea de la pureza moral y religiosa en el discurso identitario vasco», Cuadernos de Alzate, 34, 2006, pp. 41-68, p. 45. 
parecen mostrar las palabras del revolucionario vasco-francés Dithurbide, en una carta dirigida a Humboldt fechada en 1801, recogidas por Justo Gárate:

«En otro tiempo se podía conocerle en los bailes públicos, que los verdugos de misioneros han hecho abolir casi del todo. Allí las jóvenes, como las antiguas Sammitas bailaban públicamente danzas circulares bajo los ojos de sus padres y madres, de sus magistrados, de sus curas y de todos sus conciudadanos, y se retiraban a la entrada de la noche. Después, es ya otra cosa bien distinta. Los hombres van a las tabernas a emborracharse y golpearse, y las muchachas, privadas de toda diversión pública, se divierten en las esquinas en hacer niños. $\mathrm{Y}$ así, los reformadores de costumbres han pervertido las de nuestro país. Los sacerdotes jamás van derechos sino a un solo fin, que es su interés ${ }^{91}$.

Lo más destacable de este relato larramendiano sobre las danzas es, a mi juicio, que la proximidad con el sexo femenino no siempre fue concebida como peligrosa o pecaminosa. En este sentido, el jesuita se volvió a desviar de la misoginia tradicional para defender la virtud y castidad de sus participantes femeninas, al mismo tiempo que apelaba a la intachable instrucción religiosa de los habitantes de la provincia. La condición definitiva que hacía del baile zortzico una actividad inocente era que lo bailaran oriundos/as de la provincia de acuerdo a los mandatos de la tradición, valedores de un cristianismo primigenio incuestionable. En el discurso sobre las danzas, en el que identidad comunitaria, deseo y religión han aparecido estrechamente imbricadas, observamos, una vez más, que el guipuzcoanismo de Larramendi se impuso ante las creencias religiosas en torno a la feminidad y la danza que operaban en el imaginario más conservador de la época. La necesidad de defender este aspecto festivo de la provincia y la reivindicación de su superioridad moral le obligaron a revisar una vastísima literatura bíblica con la que justificar que las danzas tradicionales guipuzcoanas eran perfectamente decentes y a enfrentarse al sentir de la comunidad eclesiástica, de la que también él era parte.

91 Justo Garate, La época de Pablo Astarloa y Juan Antonio Moguel, Imprenta Provincial de Vizcaya, Bilbao, 1936, p. 22. 


\section{Conclusiones}

La diferencia sexual y la feminidad guipuzcoanas fueron en la obra de Larramendi construidas desde la necesidad de reforzar la diferencia comunitaria en un momento en el que las dinámicas políticas, sociales, los modos de vida y las costumbres estaban sujetas a modificaciones tanto en España como en Europa. Su intento de singularización, no obstante, no se limitó a repetir y plasmar el mandato de las autoridades. Fue un acto fundamentalmente creativo y en debate con sus contemporáneos que le obligó a reconsiderar, en nombre de un supuesto origen guipuzcoano primigenio, singulares redefiniciones de aspectos sociales como el trabajo, la división estamental o la moralidad de los bailes. Paradójicamente, siendo un autor de convicciones profundamente tradicionalistas, en su particular visión de Gipuzkoa se distanció de las concepciones más conservadoras de su tiempo. Y lo más importante, se vio obligado a revisar los prejuicios más virulentos en contra del sexo femenino para hacerlos compatibles con su propio proyecto comunitario. Quiso así proyectar una imagen de feminidad que fuese portadora de los valores de la provincia, la nobleza de sangre y el cristianismo primitivo. También ellas debían ser representantes del puro linaje guipuzcoano haciendo honor a su fuerza, vigor, austeridad y virtud religiosa.

Mediante nuestro análisis hemos querido mostrar que la categoría «mujeres» que operaba en este discurso estuvo mucho más condicionada por las posiciones sugeridas desde la variable comunitaria, que por la propia dimensión de género y todas las características negativas que los discursos misóginos de la época -incluido el propio Larramendile atribuían. Es decir, mediante el discurso del trabajo, el del atuendo o el de las danzas, Larramendi construyó la idea de las «mujeres guipuzcoanas» más desde su preocupación por salvaguardar el particularismo provincial que desde sus prejuicios acerca del «sexo débil». Siendo esto así, las mujeres guipuzcoanas podían ser humildes caseras, jornaleras o hilanderas, pero nunca dejarían de ser moral y físicamente superiores al resto de mujeres, y también hombres, de otras provincias porque se les exigía que incorporasen en ellas los excelsos valores del varonil pueblo guipuzcoano. Eran, en definitiva, «de valor superior a su sexo» ${ }^{92}$. El de Larramendi era un discurso tradicionalmente misógino, ya que despreciaba lo

92 Manuel de Larramendi, Corografía..., p. 50. 
femenino y lo afeminado como sinónimos de degradación. No obstante, era capaz de convivir con el ensalzamiento tanto físico como moral de ciertas mujeres por pertenecer a una comunidad que las elevaba sobre su condición biológica o su estrato social. En la jerarquización larramendiana de las categorías identitarias, el peso del particularismo provincial se impuso sobre el resto de variables, mostrando que el sexo no siempre ha sido el elemento fundamental en la construcción de la identidad de las mujeres. 